DOI: 10.1002/chem.201002934

\title{
Immobilization of DNA on Magnetic Microparticles for Mercury Enrichment and Detection with Flow Cytometry
}

\author{
Po-Jung Jimmy Huang and Juewen Liu*[a]
}

\begin{abstract}
Mercury detection in water has attracted a lot of research interest due to its highly toxic nature and adverse environmental impact. In particular, the recent discovery of specific binding of $\mathrm{Hg}^{\text {(II) }}$ to thyminerich DNA resulting in $\mathrm{T}-\mathrm{Hg}^{(\mathrm{II})} \mathrm{T}$ base pairs has led to the development of a number of sensors with different signaling mechanisms. However, majority of such sensors were nonimmobilized. Immobilization, on the other hand, allows active mercury adsorption, signal amplification, and
\end{abstract}

sensor regeneration. In this work, we immobilized a thymine-rich DNA on a magnetic microparticle surface via biotin-streptavidin interactions. In the presence of $\mathrm{Hg}^{(\mathrm{II})}$, the DNA changes from a random coil structure into a hairpin, upon which SYBR Green I binds to emit green fluorescence. Detection was carried out using flow cytometry where fluorescence intensity increased $\sim 9$-fold in the presence of mercury and the binding of mercury reached equilibrium in less than $2 \mathrm{~min}$. The sensor showed a unique sample- volume dependent fluorescence signal change where a higher fluorescence was obtained with a larger sample volume, suggesting that the particles can actively adsorb $\mathrm{Hg}^{(\mathrm{II})}$. Detection limits of $5 \mathrm{nM}(1 \mathrm{ppb})$ and $14 \mathrm{nM}(2.8$ $\mathrm{ppb})$ were achieved in pure buffer and in mercury spiked Lake Ontario water samples, respectively.

Keywords: mercury $\bullet$ DNA • fluorescence $\bullet$ flow cytometry $\bullet$ magnetic microparticles -immobilization

\section{Introduction}

Mercury is a highly toxic and bioaccumulative heavy metal ${ }^{[1,2]}$ leading to immunological disorders, kidney damages, neurological and other chronic diseases upon long-term exposure. ${ }^{[3,4]}$ There are a number of natural and human related sources that introduce mercury and its derivatives into the environment. ${ }^{[3]}$ Thousands of tons of mercury is released each year and eventually enters the natural water resources of the world. Therefore, mercury poses a worldwide threat to public health and the environment, and detection of mercury in water has attracted a lot of research interest. ${ }^{[1,5]}$

There are a number of analytical techniques developed with exceptional sensitivity for mercury detection, including various types of spectrometry, voltammetry, and chromatography. ${ }^{[5]}$ However, many of these methods require complicated sample preparation and sophisticated instrumentations. An alternative approach towards mercury detection is to develop portable

[a] P-J Huang, Prof. Dr. J. Liu

Department of Chemistry, Waterloo Institute for Nanotechnology University of Waterloo

200 University Avenue West, Waterloo, Ontario, N2L 3G1 (Canada) Fax: (+1) 519-746-0435

E-mail: liujw@uwaterloo.ca sensors. ${ }^{[1]}$ Such sensors have been designed for mercury detection in water using small molecule chelators, ${ }^{[6-8]}$ proteins, ${ }^{[9,}{ }^{10]}$ conjugated polymers, ${ }^{[11]}$ nanoparticles, ${ }^{[12]}$ and genetically modified cells. ${ }^{[13]}$ Some of the sensors have been used for the detection of mercury in environmental and biological samples. ${ }^{[8,14-17]}$

In 2004, a mercury sensor based on a thymine-rich singlestranded (ss) DNA was first reported. ${ }^{[18]}$ While thymine binding to mercury has been known for a long time, ${ }^{[19,20]}$ this study was the first attempt to use a thymine-rich DNA for mercury detection. Since then, this DNA-based mercury recognition mechanism has been used to design many fluorescent, ${ }^{[16,17,21-25]}$ colorimetric, ${ }^{[11,26-}$ ${ }^{35]}$ and electrochemical sensors. ${ }^{[36]}$ Currently, detection limits in the low nanomolar range can be reached. Therefore, in principle such sensors can be used for mercury analysis in water, where, according to the US Environmental Protection Agency (EPA), the toxic limit for mercury in drinking water is $10 \mathrm{nM}$ or 2 parts-per-billion (ppb).

Majority of the reported mercury sensors were freely dispersed in solution for a proof-of-concept. Sensor immobilization, on the other hand, offers many potential advantages including sensor regeneration, mercury adsorption/enrichment, and signal amplification. Among the various materials available for immobilization, we chose magnetic microparticles (MMPs) because it has a large surface area allowing a high DNA immobilization density. At the same time, flow cytometry can be used for the analysis of particle fluorescence. Furthermore, MMPs can be easily collected with a magnet, allowing mercury enrichment and sensor regeneration to be conveniently carried out. MMPs have been used 
for the detection of DNA, ${ }^{[37,38]}$ small molecules, ${ }^{[39]}$ toxins, ${ }^{[40]}$ proteins, ${ }^{[41-43]}$ and cells. ${ }^{[4]}$ For most of the assays, covalent fluorophore labeling was required for fluorescence generation.

Herein, we demonstrate highly sensitive and selective mercury detection using thymine-rich DNA-functionalized MMPs, where no covalent fluorophore attachment is required. The sensor shows a unique sample volume dependent signal change, confirming the ability of mercury enrichment on the particle surface. The sensor performance has been systematically characterized in pure buffer solutions and in Lake Ontario water samples. Finally, sensor regeneration was demonstrated. With portable flow cytometers becoming available, such bead-based assays are likely to have important environmental and analytical applications. ${ }^{[45,46]}$

\section{Results and Discussion}

MMP-based $\mathbf{H g}^{(\mathrm{II})}$ Detection. The sequence of mercury binding DNA is shown in Figure 1A. This DNA has been widely used for mercury detection since its first report in 2004. ${ }^{[18]}$ Each DNA contains seven hypothetic mercury binding sites. In the presence of $\mathrm{Hg}^{(\mathrm{II})}$, the DNA folds into a hairpin structure; while in the absence of $\mathrm{Hg}^{(\mathrm{II})}$, it has a random coil structure. The original design took advantage of the end-to-end distance change of the DNA upon $\mathrm{Hg}^{(\mathrm{II})}$ binding and fluorescence energy transfer was employed for signal generation. ${ }^{[18]}$ Being highly sensitive, the need for covalent fluorophore/quencher modification makes the cost of synthesis very high. We chose to use DNA intercalation dyes such as SYBR Green I for signal generation to omit the need for covalent DNA modification (Figure 1A). ${ }^{[23]}$ In the presence of $\mathrm{Hg}^{\text {(II) }}$, SYBR Green I binds to the double-stranded region of the DNA through intercalation and minor groove binding ${ }^{17}$ to generate a strong fluorescence. In the absence of $\mathrm{Hg}^{(I I)}$, the dye binds to the ssDNA through electrostatic interactions with a much lower affinity, giving a very low fluorescence background. As shown in Figure 2A, with a DNA concentration of $15 \mathrm{nM}$ and SYBR Green I concentration of 90 $\mathrm{nM}$, there is a 14-fold fluorescence enhancement upon addition of $100 \mathrm{nM} \mathrm{Hg}^{\text {(II) }}$.

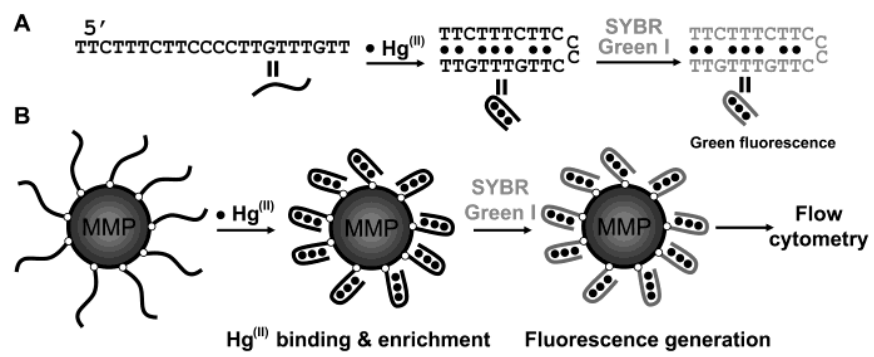

Figure 1. (A) The $\mathrm{Hg}^{(\mathrm{II})}$-binding DNA sequence and SYBR Green I-based fluorescence signal generation. (B) The 5'-end of the DNA was modified with a biotin (denoted as white dots) to bind to streptavidin coated $2.8 \mu \mathrm{m}$ diameter MMPs. The functionalized MMPs can enrich mercury and generate a highly fluorescent particle that can be analyzed using flow cytometry.
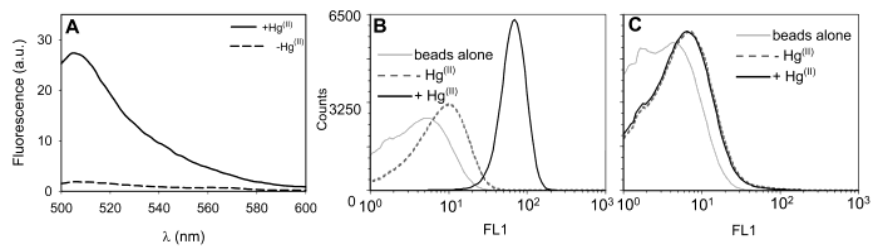

Figure 2. (A) Steady-state fluorescence spectra of $15 \mathrm{nM}$ mercury binding DNA and 90 nM SYBR Green I in the presence and absence of $100 \mathrm{nM} \mathrm{Hg}^{(\mathrm{II})}$. A 14-fold fluorescence enhancement was observed. Flow cytometry histograms of MMPs functionalized with the mercury binding DNA (B) and control DNA (C). The added $\mathrm{Hg}^{(\mathrm{II})}$ concentration was
$100 \mathrm{nM}$ for both samples. SYBR Green I was not added to the beads alone sample but to the other two samples. The $x$-axis is the fluorescence intensity in the FAM channel on the log scale, and the $y$-axis is the number of MMPs at each fluorescence intensity. The buffer used for all of the samples contained $150 \mathrm{mM} \mathrm{NaNO}_{3}, 8 \mathrm{mM}$ Tris-nitrate, $\mathrm{pH}$ 7.5.

To immobilize DNA on a streptavidin coated MMP, the DNA was biotinylated on the $5^{\prime}$-end and the detection was achieved using flow cytometry (Figure 1B). Flow cytometry is a commonly used technique, which employs fluorescence and light scattering for analyzing microparticles and cells one-by-one. However, its application in environmental monitoring has not been well developed. With portable flow cytometers becoming available, ${ }^{[47,48]}$ this type of platform will find important applications in analysis of water or other types of environmental samples.

Under our experimental conditions, the DNA-functionalized MMPs showed a weak fluorescence peak at $\sim 4.0$ (Figure 2B, solid gray curve). With the addition of SYBR Green I, the peak intensity increased slightly to $\sim 8.0$. After adding $100 \mathrm{nM}$ of $\mathrm{Hg}^{\text {(II) }}$, the peak shifted to $\sim 80$, which corresponds to a $\sim 9$-fold fluorescence enhancement. Such a strong fluorescence increase supports that this MMP-based sensor can also be used for highly sensitive mercury detection. To confirm that the observed fluorescence change was indeed due to the proposed DNA binding as shown in Figure 1A, a control experiment was designed. Another biotinylated DNA (but not thymine rich) was immobilized and tested. As shown in Figure $2 \mathrm{C}$, very little fluorescence increase was observed in the presence of $\mathrm{Hg}^{(\mathrm{II})}$, suggesting that the observed fluorescence shift in Figure 2B was due to DNA sequence specific binding of $\mathrm{Hg}^{(\mathrm{II})}$ instead of artifacts due to immobilization.

Sample Volume Dependent Signal. For non-immobilized sensors, the sensor signal is usually limited by the analyte concentration. After immobilization, each MMP carries millions of DNA strands and can actively and selectively adsorb mercury. In particular for MMPs, they can be easily collected using a magnet. Therefore, MMPs may increase signal and sensitivity by simply using a larger sample volume. For most environmental monitoring applications, a large sample volume can usually be achieved. To test this, sample volumes from 0.05 to $3 \mathrm{~mL}$ were used, all containing $20 \mathrm{nM} \mathrm{Hg}^{\text {(II) }}$. As shown in Figure 3A, the fluorescence histogram shifted to higher fluorescence with an increase of sample volume, suggesting that more $\mathrm{Hg}^{(\mathrm{II})}$ was associated with each particle. If the average fluorescence intensity is plotted (Figure 3B), a linear increase from 0.05-1.5 mL was observed. Furthermore an increase of sample volume did not increase the signal further. Therefore, $1.5 \mathrm{~mL}$ was chosen for further testing of the sensor performance.
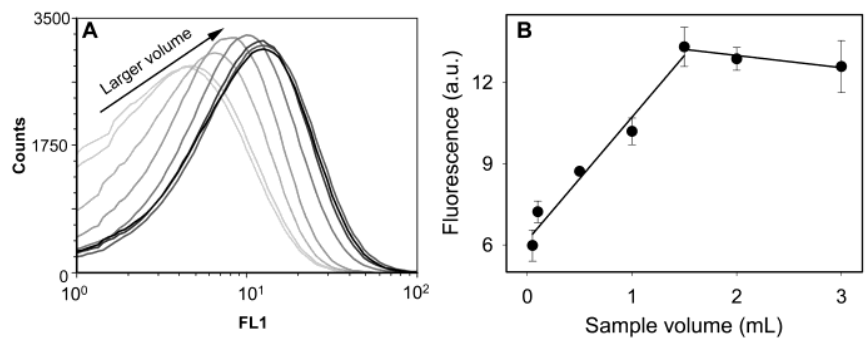

Figure 3. Sample volume-dependent fluorescence signal change. (A) The original flow cytometry histograms. (B) Quantification based on the average fluorescence from (A). The data were fit using two lines that intersect at $1.5 \mathrm{~mL}$. The standard deviations from three independent samples are represented by the error bars.

Kinetics of $\mathbf{H g}^{(\mathrm{II})}$ Binding. One of the important factors for sensing is the kinetics of signal change. Since the DNA was immobilized, the kinetics of fluorescence change might be slower due to diffusion 
of $\mathrm{Hg}^{\text {(II) }}$ to the particle surface. To understand this, we mixed $1 \mu \mathrm{L}$ of the functionalized MMPs with $1.5 \mathrm{~mL}$ of 50 or $100 \mathrm{nM} \mathrm{Hg}^{(\mathrm{II})}$ for a time ranging from $2 \mathrm{~min}$ to $1 \mathrm{hr}$. After that, SYBR Green I was added and the beads were analyzed using flow cytometry. As shown in Figure 4, a stable signal was generated in the first 2 min, which was the shortest time achievable using the manual operations. It has been previously reported that the binding kinetics between an nonimmobilized thymine-rich DNA and mercury is instantaneous and a stable signal can be achieved within several seconds. ${ }^{[16]}$ Therefore, immobilization on MMPs does not appear to adversely affect the signaling generation kinetics. In the time scale practical for this immobilized sensor, the response was also very fast and stable. This study also shows that a high $\mathrm{Hg}^{\text {(II) }}$ concentration gave a higher fluorescence, allowing quantitative mercury detection.

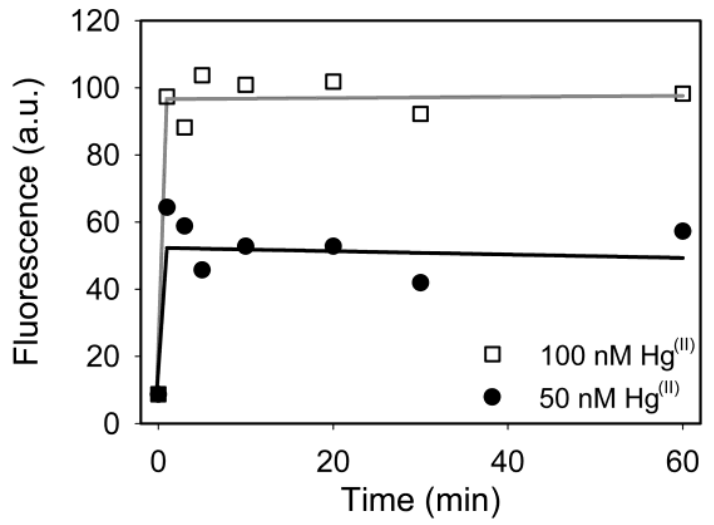

Figure 4. Kinetics of fluorescence change after mixing MMPs with $\mathrm{Hg}^{(\mathrm{II})}$. Saturated signal was observed after $2 \mathrm{~min}$ of incubation, suggesting fast $\mathrm{Hg}^{(\mathrm{II})}$ binding. The data points from 2 to $60 \mathrm{~min}$ were fit with a line whose slope is close to zero, this suggests that the fluorescence signal was stable after $2 \mathrm{~min}$.

It needs to be pointed out that the result from flow cytometry analysis is largely independent of the number of particles counted as long as the particle number is sufficiently high. In this study, we count at least 15,000 particles for each sample, which takes about 30 sec.

Sensitivity and Selectivity. To test the sensitivity of this immobilized mercury sensor, the sensor beads were mixed with various concentrations of $\mathrm{Hg}^{\text {(II) }}$ and analyzed using flow cytometry. As $\mathrm{Hg}^{(\mathrm{II})}$ concentration was increased, a gradual shift of the fluorescence peak was observed before the signal reached saturation at $\sim 100 \mathrm{~nm}$ (Figure 5A). If the average fluorescence is plotted, a linear relationship is obtained up to $100 \mathrm{nM} \mathrm{Hg}^{\text {(II) }}$ (Figure 5B). At even higher $\mathrm{Hg}^{\text {(II) }}$ concentrations, the signal became saturated. A detection limit of $5.0 \mathrm{nM} \mathrm{Hg}^{\text {(II) }}$ was achieved using the $3 \sigma /$ slope calculation. This sensitivity is among the highest from all of the reported $\mathrm{Hg}^{(\mathrm{II})}$ sensors. In addition, this dynamic range covers EPA established drinking water toxic level of $10 \mathrm{nM} \mathrm{Hg}^{\text {(II) }}$. Interestingly, the non-immobilized sensor with the same signaling mechanism has a detection limit of $1.33 \mathrm{nM},{ }^{[23]}$ suggesting that the sensor performance has been largely maintained after immobilization.
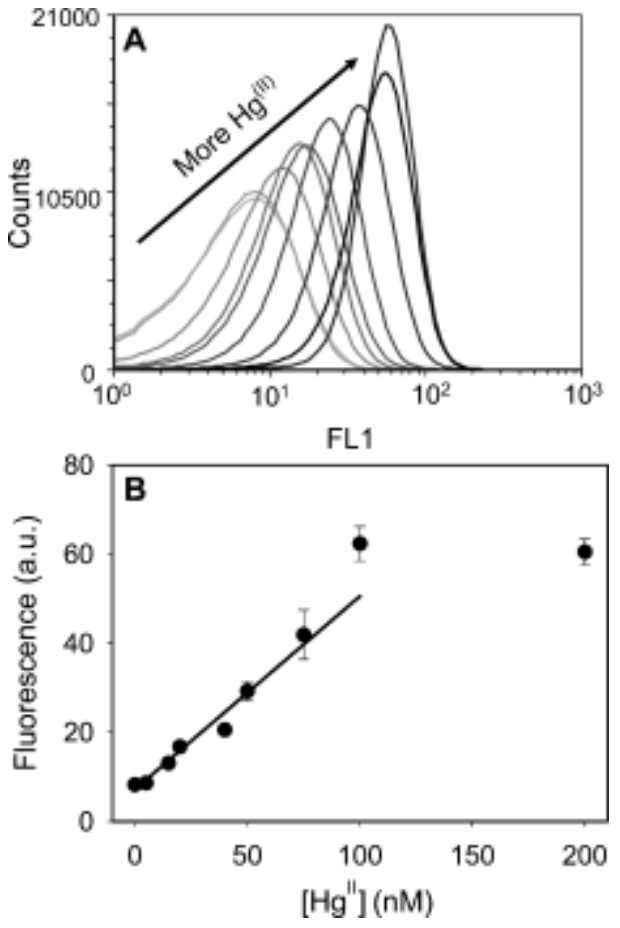

Figure 5. Sensitivity test. (A) Flow cytometry histograms of DNA-functionalized MMPs as a function of $\mathrm{Hg}^{\text {(II) }}$ concentration. (B) Quantification of the average fluorescence as a function of $\mathrm{Hg}^{\text {(II) }}$ concentration. The data from 0 to $100 \mathrm{nM}$ were fit to a line for calculating the detection limit.

As specified by the vendor, $\sim 1.8 \times 10^{6}$ biotinylated ssDNA can be immobilized on the surface of each particle. Using a fluorescently labeled biotinlylated DNA containing 37 nucleotides (37-mer), we previously achieved a density of $\sim 1.2 \times 10^{6}$ DNA per particle. ${ }^{[39]}$ Since this $\mathrm{Hg}^{\text {(II) }}$ binding DNA contains only 22 nucleotides, the density should be even higher. Assuming that all of the binding sites are saturated by the DNA (e.g. $7 \mathrm{Hg}^{\text {(II) }}$ ions for each DNA), $1 \mu \mathrm{L}$ MMPs $\left(\sim 6.5 \times 10^{5}\right.$ particles $)$ can bind $\sim 8 \times 10^{12}$ $\mathrm{Hg}^{(\mathrm{II})}$. This is equivalent to $9 \mathrm{nM} \mathrm{Hg}^{(\mathrm{II})}$ in a volume of $1.5 \mathrm{~mL}$. However, our result showed that fluorescence signal saturated only in the presence of $100 \mathrm{nM} \mathrm{Hg}^{(\mathrm{II})}$. This suggests that the binding between the DNA and $\mathrm{Hg}^{(\mathrm{II})}$ is not quantitative in our system.

We next tested the selectivity of this detection method. As shown in figure $6 \mathrm{~A}$, only $\mathrm{Hg}^{\text {(II) }}$ showed a large fluorescence shift in the flow histogram at a concentration of $100 \mathrm{nM}$. All of the other metal ions showed a signal close to the blank sample where no additional metal ions were added (Figure 6B). The data suggests that the high selectivity of the DNA was not compromised due to immobilization. We further tested the sensor response with $100 \mathrm{~nm}$ $\mathrm{Hg}^{(\mathrm{II})}$ in the presence of 10,000 -fold excess of $\mathrm{Mg}^{(\mathrm{II})}$ and $\mathrm{Ca}^{(\mathrm{II})}$ (1 $\mathrm{mM}$ each) and 1000-fold excess of other metal ions (100 $\mu \mathrm{M}$ each). As shown in Figure $6 \mathrm{C}$, only $\mathrm{Fe}^{(\mathrm{III})}$ and $\mathrm{Ag}^{(\mathrm{I})}$ interfered with the detection by quenching the fluorescence. For all of the other metal ions, responses similar to that of $\mathrm{Hg}^{(\mathrm{II})}$ alone were observed. 

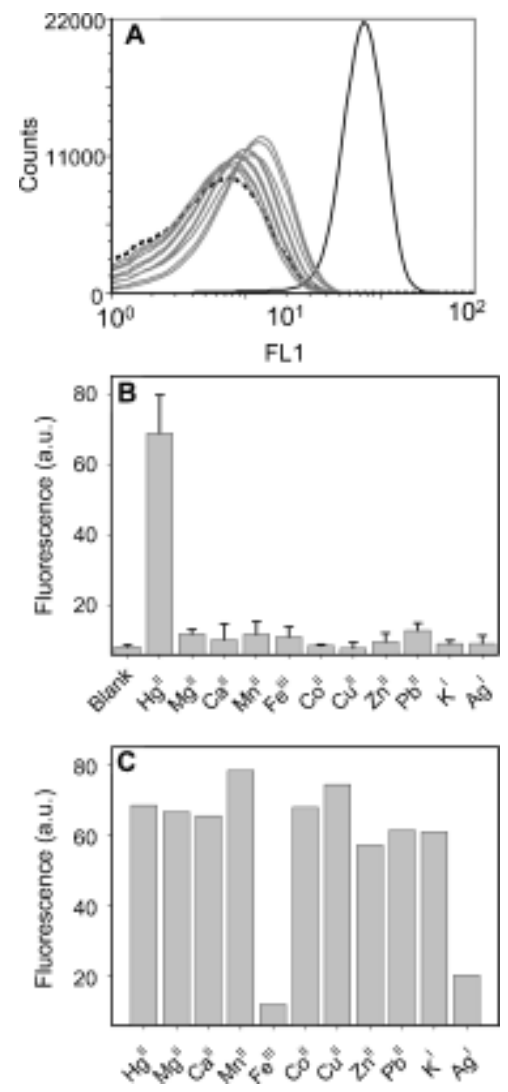

Figure 6. (A) Flow cytometry histograms of the sensor in the presence of various metal ions (100 nM each). (B) Bar graph showing the average fluorescence. Only mercury showed high fluorescence, suggesting high selectivity of the sensor. (C) Interference study. The sensor response of $100 \mathrm{nM} \mathrm{Hg}^{\text {(II) }}$ (the first bar) and $100 \mathrm{nM} \mathrm{Hg}^{\text {(II) }}$ in the presence of also $1 \mathrm{mM} \mathrm{Mg}{ }^{(\mathrm{II})}, \mathrm{Ca}^{(\mathrm{II})}$ or $100 \mu \mathrm{M}$ other metal ions.

Detection in Lake Ontario Water. To evaluate the sensor performance in an environmental sample, Lake Ontario water samples were tested. Since there is no $\mathrm{Hg}^{(\mathrm{II})}$ in the water samples as analyzed by ICP-MS, $\mathrm{Hg}^{(\mathrm{II})}$ was added for measurement. As can be seen from Figure 7 (solid dots), the samples showed a $\mathrm{Hg}^{(\mathrm{II})}$ dependent fluorescence shift. The background fluorescence in the absence of mercury, however, was higher compared to that in the buffer. We calculated a detection limit of $\sim 14 \mathrm{nM} \mathrm{Hg}^{\text {(II) }}$ in the Lake Ontario water samples. This sensitivity was slightly lower in comparison to the value in the pure buffer solution ( $5 \mathrm{nM})$. We also found that the slope of the two sensitivity curves were quite similar (0.43 and 0.39 fluorescence unit/nM $\mathrm{Hg}^{\text {(II) }}$ for pure buffer and lake water, respectively). The main difference that brought the detection limit down for the lake water sample was the background variation. Since the background was higher for the lake water, its variation was also larger. To test the origin of the high background fluorescence in the absence of mercury, we mixed DNAfunctionalized MMPs with the lake water (without added $\mathrm{Hg}^{(\mathrm{II})}$ or SYBR Green). No fluorescence increase was observed (Figure 7B), suggesting that the observed background fluorescence was not due to adsorption of fluorophores in the lake water.
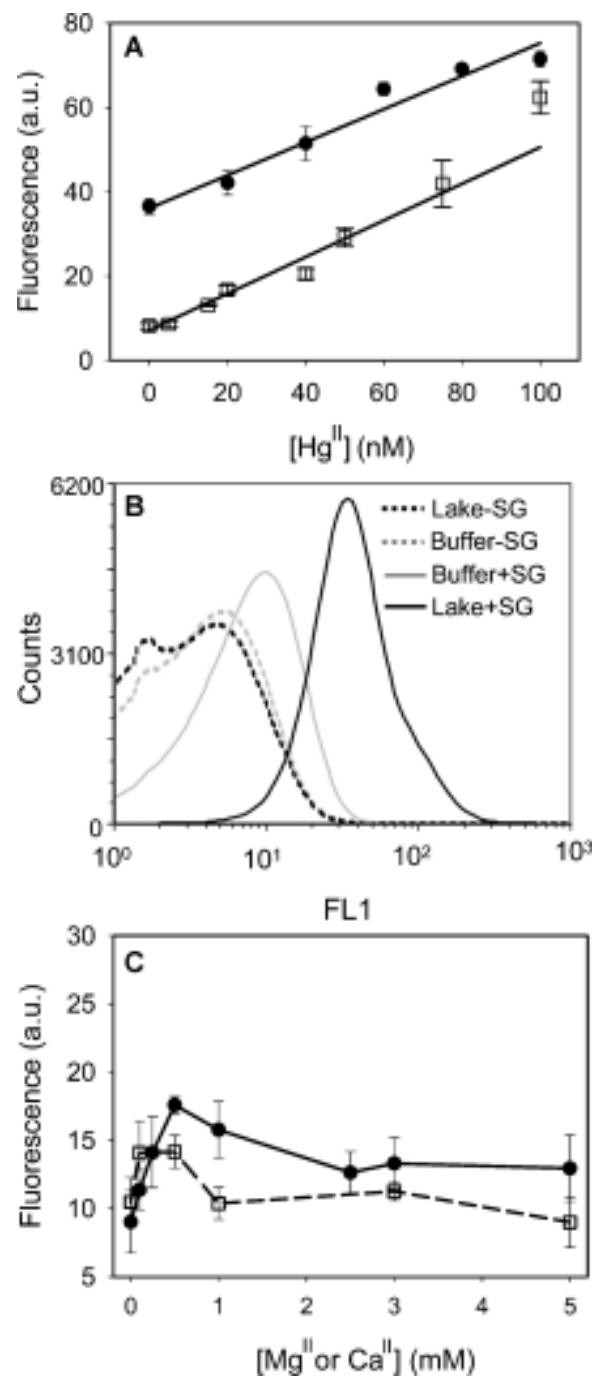

Figure 7. (A) $\mathrm{Hg}^{\text {(II) }}$-dependent fluorescence of the sensor in spiked Lake Ontario water samples. For comparison, the sensor response in pure buffer is also shown. (B) Flow cytometry histograms of MMPs in the buffer or Lake Ontario water with no added $\mathrm{Hg}^{\text {(II) }}$. In the legend, SYBR denotes for SYBR Green I dye. (C) Sensor fluorescence as a function of $\mathrm{Ca}^{(\mathrm{III})}$ or $\mathrm{Mg}^{(\mathrm{II})}$ concentration up to $5 \mathrm{mM}$.

Natural water samples such as Lake Ontario can contain high concentrations of various metal ions such as $\mathrm{Ca}^{(\mathrm{II})}$ and $\mathrm{Mg}^{(\mathrm{II})}$. In the case of Lake Ontario, $0.36 \mathrm{mM} \mathrm{Mg}$ (II) and $0.84 \mathrm{mM} \mathrm{Ca}^{(\mathrm{II})}$ was present in the water in 2008. ${ }^{[49]}$ To further understand the behavior of our sensor in the presence of high concentrations of these metal ions, we mixed the sensor with buffers containing these metals. As shown in Figure 7C, there is a concentration dependent fluorescence increase up to $0.5 \mathrm{mM} \mathrm{Mg}^{\text {(II) }}$, at which a fluorescence value of $\sim 18$ was observed. A similar trend was also observed for $\mathrm{Ca}^{(\mathrm{II})}$. Therefore, the presence of these metal ions in the Lake water may explain the observed high background fluorescence. $\mathrm{Mg}^{(\mathrm{II})}$ or $\mathrm{Ca}^{\text {(II) }}$ is not known to have specific interactions with thymine bases. Therefore, we attribute the observed fluorescence increase to electrostatic binding between these metal ions to the DNA phosphate backbone, which folds DNA into a more compact structure resulting in SYBR Green 1 interacting more strongly with the DNA. Interestingly, a further increase of these metal ions resulted in decreasing the fluorescence, possibly due to quenching of the SYBR Green I dye. ${ }^{[50]}$ Even with $0.5 \mathrm{mM} \mathrm{Mg}^{(\mathrm{II})}$, the fluorescence was still less than half of that with $100 \mathrm{nM} \mathrm{Hg} \mathrm{Hg}^{\text {(II) }}$. Therefore, the selectivity for $\mathrm{Hg}^{(\mathrm{II})}$ was still over 10,000 -fold higher for $\mathrm{Hg}^{(\mathrm{II})}$. 
Sensor Regeneration. Since mercury recognition and signal generation in our system was based on reversible binding interactions, the sensor can be regenerated by simply removing $\mathrm{Hg}^{(\mathrm{II})}$. We chose to use EDTA for mercury removal the MMPs were collected with a magnet. As shown in Figure 8, the MMPs showed a high fluorescence upon $\mathrm{Hg}^{(\mathrm{II})}$ addition. After incubating with $1 \mathrm{mM}$ EDTA for $20 \mathrm{~min}$ and washing three times with buffer, the fluorescence shifted back to the background level. This indicates that $\mathrm{Hg}^{(\mathrm{II})}$ was completely removed and the sensor was regenerated. This process was repeated for five cycles and the sensor maintained its mercury detection ability after each regeneration step, suggesting that the conjugation between DNA and MMP was very stable and can survive repeated washing processes.

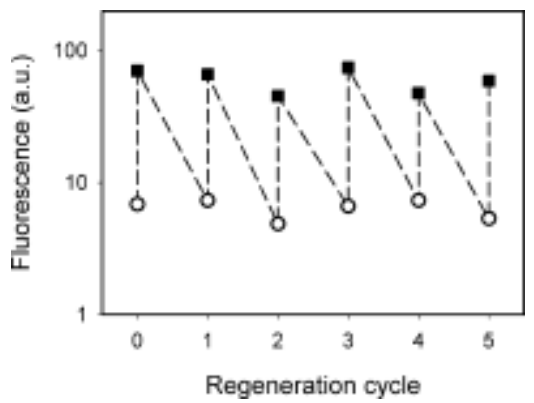

Figure 8. Sensor regeneration by adding EDTA and washing with buffer. A total of five regeneration cycles have been performed.

\section{Conclusion}

In summary we have immobilized a DNA-based fluorescent mercury sensor on MMPs and used flow cytometry for detection purposes. We have explored the various features of the sensor that was made possible through immobilization. For example, this sensor showed a unique sample volume dependent response, fast and stable signal change, regeneration, and high sensitivity and selectivity. It is also possible to achieve mercury detection in natural water samples, and potential interfering ions have been identified. With the development of portable flow cytometers, such magnetic microparticle-based assays will find more applications in environmental monitoring and analytical chemistry.

\section{Experimental Section}

Materials. The DNA samples were purchased from Integrated DNA Technologies Inc. (Coralville, IA, USA). The $\mathrm{Hg}^{(\mathrm{II})}$ binding DNA has a sequence of $5^{\prime}$-biotinTTCTTTCTTCCCCTTGTTTGTT. The control DNA sequence is 5'-biotinATCATCATCATCATCGTCAAGAATGCTGACC. Streptavidin-coated $2.8 \mu \mathrm{m}$ Dynabeads (M-270) and 10000× SYBR Green I in anhydrous dimethyl sulfoxide (DMSO) were purchased from Invitrogen (Carlsbad, CA). Mercury chloride, coppe sulfate, zinc chloride, manganese chloride, iron chloride, cobalt chloride, lead acetate, magnesium chloride, and calcium chloride were acquired from Sigma-Aldrich (St Louis, MO). Sodium nitrate, ethylenediaminetetraacetic acid (EDTA) and tris(hydroxymethyl) aminomethane (Tris) were obtained from Mandel Scientific (Guelph, Ontario, Canada). All buffers and solutions were prepared using Millipore water.

DNA Conjugation. Vendor's recommended protocols were followed for DNA conjugation. The preservatives on the MMPs were removed with $2 \times$ binding $\&$ washing $(\mathrm{B} \& \mathrm{~W})$ buffer $(10 \mathrm{mM}$ Tris- $\mathrm{HCl}, \mathrm{pH} 7.5,1 \mathrm{mM}$ EDTA, and $2 \mathrm{M} \mathrm{NaCl})$ and were temporarily stored in $1 \times \mathrm{B} \& \mathrm{~W}$ buffer. For DNA conjugation, slight excess of DNA was used to ensure the entire surface of the MMPs were saturated with DNA. Specifically, 3 $\mu \mathrm{L}$ of $1 \mu \mathrm{M}$ biotinylated $\mathrm{Hg}^{\text {(II) }}$ DNA was coupled with $1 \mu \mathrm{L}$ of MMPs at room temperature for 20-30 min. Excess of DNA was removed with the help of a magnet. The
DNA coated MMPs were then washed with $1 \times \mathrm{B} \& \mathrm{~W}$ buffer $(3 \times 50 \mu \mathrm{L})$ and buffer A $\left(150 \mathrm{mM} \mathrm{NaNO}_{3}, 8 \mathrm{mM}\right.$ Tris-nitrate, $\left.\mathrm{pH} 7.5,3 \times 50 \mu \mathrm{L}\right)$.

$\mathbf{H g}^{\text {(II) }}$ Detection. $1 \mu \mathrm{L}$ of functionalized MMPs was reacted with various amount of $\mathrm{Hg}^{(\mathrm{III})}$ in $1.5 \mathrm{~mL}$ of buffer $\mathrm{A}$ at room temperature for $\sim 1 \mathrm{hr}$. The buffer volume was reduced to $50 \mu \mathrm{L}$ before $2 \mu \mathrm{L}$ of $25 \times$ concentrated $(50 \mu \mathrm{M})$ SYBR Green I was added. Subsequently, $250 \mu \mathrm{L}$ of the incubation buffer was reintroduced to each sample tube to give a final total volume of $300 \mu \mathrm{L}$ prior to flow cytometry analysis. The fluorescence was then measured with a BD FACSVantage SE flow cytometer. At least 15000 events were counted for each sample.

Volume Dependent and Kinetic Studies. For volume dependent studies, the sensor particles were incubated in various volumes of buffer A, all containing $20 \mathrm{nM}$ of $\mathrm{Hg}^{\text {(II) }}$ for $\sim 1 \mathrm{hr}$. For kinetic studies, the sensor was incubated in $1.5 \mathrm{~mL}$ buffer A with 50 or $100 \mathrm{nM} \mathrm{Hg}^{(\mathrm{II})}$. The fluorescence was measured with the flow cytometer at designated time points.

Sensor Regeneration. To regenerate the sensor after the addition of $100 \mathrm{nM} \mathrm{Hg}^{(\mathrm{II})}$, the functionalized MMPs were soaked in $1.5 \mathrm{~mL}$ of $1 \mathrm{mM}$ EDTA for at least $20 \mathrm{~min}$. The EDTA solution was then discarded and the MMPs were further washed with buffer A (3 $\times 100 \mu \mathrm{L})$.

Detection of $\mathbf{H g}^{(\mathrm{II})}$ in Lake Ontario Water Samples. Lake Ontario water samples were collected from Colonel Samuel Smith Park in Toronto, Ontario, Canada. Since the result of ICP-MS analysis showed no detectable mercury, $\mathrm{Hg}\left(\mathrm{ClO}_{4}\right)_{2}$ was added to simulate contaminated natural water source. Other operations were the same as that in the pure buffer solutions.

\section{Acknowledgements}

We are grateful for the help of Mihaela Savulescu for flow cytometry analysis. This work is supported by the University of Waterloo and the Natural Sciences and Engineering Research Council (NSERC) of Canada.

[1] E. M. Nolan and S. J. Lippard, Chem. Rev. 2008, 108, 34433480.

[2] J. G. Dorea and C. M. Donangelo, Clin. Nutr. 2006, 25, 369-376. [3] T. W. Clarkson, L. Magos and G. J. Myers, N. Engl. J. Med. 2003, 349, 1731-1737.

[4] P. B. Tchounwou, W. K. Ayensu, N. Ninashvili and D. Sutton, Environ. Toxicol. 2003, 18, 149-175.

[5] W. L. Clevenger, B. W. Smith and J. D. Winefordner, Crit. Rev. Anal. Chem. 1997, 27, 1-26.

[6] E. M. Nolan and S. J. Lippard, J. Am. Chem. Soc. 2003, 125, 14270-14271.

[7] E. M. Nolan and S. J. Lippard, J. Am. Chem. Soc. 2007, 129, 5910.

[8] S. Yoon, E. W. Miller, Q. He, P. H. Do and C. J. Chang, Angew. Chem. Int. Ed. 2007, 46, 6658-6661.

[9] P. Chen and C. He, J. Am. Chem. Soc. 2004, 126, 728-729.

[10] S. V. Wegner, A. Okesli, P. Chen and C. He, J. Am. Chem. Soc. 2007, 129, 3474-3475.

[11] X. F. Liu, Y. L. Tang, L. H. Wang, J. Zhang, S. P. Song, C. H. Fan and S. Wang, Adv. Mater. 2007, 19, 1471-1474.

[12] C. C. Huang, Z. Yang, K. H. Lee and H. T. Chang, Angew. Chem. Int. Ed. 2007, 46, 6824-6828.

[13] M. Virta, J. Lampinen and M. Karp, Anal. Chem. 1995, 67, 667-669.

[14] C. C. Huang and H. T. Chang, Anal. Chem. 2006, 78, 83328338 .

[15] W. H. Chan, R. H. Yang and K. M. Wang, Anal. Chim. Acta 2001, 444, 261-269.

[16] C. K. Chiang, C. C. Huang, C. W. Liu and H. T. Chang, Anal. Chem. 2008, 80, 3716-3721.

[17] N. Dave, P.-J. J. Huang, M. Y. Chan, B. D. Smith and J. Liu, J. Am. Chem. Soc. 2010, 132, 12668-12673. 
[18] A. Ono and H. Togashi, Angew. Chem., Int. Ed. 2004, 43, 4300-4302.

[19] S. Katz, J. Am. Chem. Soc. 1952, 74, 2238-2245.

[20] L. D. Kosturko, C. Folzer and R. F. Stewart, Biochemistry 1974, 13, 3949-3952.

[21] J. Liu and Y. Lu, Angew. Chem., Int. Ed. 2007, 46, 7587-7590.

[22] Z. Wang, J. H. Lee and Y. Lu, Chem. Comm. 2008, 6005-6007.

[23] J. Wang and B. Liu, Chem. Comm. 2008, 4759-4761.

[24] H. Wang, Y. X. Wang, J. Y. Jin and R. H. Yang, Anal. Chem. 2008, 80, 9021-9028.

[25] B.-C. Ye and B.-C. Ying, Angew. Chem., Int. Ed. 2008, 47, 8386-8389.

[26] J.-S. Lee, M. S. Han and C. A. Mirkin, Angew. Chem., Int. Ed. 2007, 46, 4093-4096.

[27] C. W. Liu, Y. T. Hsieh, C. C. Huang, Z. H. Lin and H. T. Chang, Chem. Comm. 2008, 2242-2244.

[28] X. J. Xue, F. Wang and X. G. Liu, J. Am. Chem. Soc. 2008, 130, 3244-3245.

[29] D. Li, A. Wieckowska and I. Willner, Angew. Chem. Int. Ed. 2008, 47, 3927-3931.

[30] S. J. He, D. Li, C. F. Zhu, S. P. Song, L. H. Wang, Y. T. Long and C. H. Fan, Chem. Comm. 2008, 4885-4887.

[31] J. Lee, H. Jun and J. Kim, Adv. Mater. 2009, 21, 3674-3677.

[32] R. Freeman, T. Finder and I. Willner, Angew. Chem., Int. Ed. 2009, 48, 7818-7821.

[33] T. Li, B. L. Li, E. K. Wang and S. J. Dong, Chem. Comm. 2009, 3551-3553.

[34] N. Lu, C. Y. Shao and Z. X. Deng, Analyst 2009, 134, 18221825.

[35] Z. D. Liu, Y. F. Li, J. Ling and C. Z. Huang, Environ. Sci. Technol. 2009, 43, 5022-5027.

[36] S.-J. Liu, H.-G. Nie, J.-H. Jiang, G.-L. Shen and R.-Q. Yu, Anal. Chem. 2009, 81, 5724-5730.
[37] S. H. Lim, F. Bestvater, P. Buchy, S. Mardy and A. D. C. Yu, Sensors 2009, 9, 5590-5599.

[38] H. Xu, M. Y. Sha, E. Y. Wong, J. Uphoff, Y. Xu, J. A. Treadway, A. Truong, E. O'Brien, S. Asquith, M. Stubbins, N. K. Spurr, E. H. Lai and W. Mahoney, Nucleic Acids Res. 2003, 31, e43. [39] P. J. J. Huang and J. W. Liu, Anal. Chem. 2010, 82, 4020-4026. [40] Y. Kwon, C. A. Hara, M. G. Knize, M. H. Hwang, K. S. Venkateswaran, E. K. Wheeler, P. M. Bell, R. F. Renzi, J. A. Fruetel and C. G. Bailey, Anal. Chem. 2008, 80, 8416-8423.

[41] J. Wang, X. Wang, L. Ren, Q. Wang, L. Li, W. Liu, Z. Wan, L. Yang, P. Sun, L. Ren, M. Li, H. Wu, J. Wang and L. Zhang, Anal. Chem. 2009, 81, 6210-6217.

[42] Y. H. Tennico, D. Hutanu, M. T. Koesdjojo, C. M. Bartel and V. T. Remcho, Anal. Chem. 2010, 82, 5591-5597.

[43] S. Centi, S. Tombelli, M. Minunni and M. Mascini, Anal. Chem. 2007, 79, 1466-1473.

[44] K. Hibi, H. Ushio, H. Fukuda, K. Mitsubayashi, T. Hayashi, H. Ren and H. Endo, Anal. Bioanal. Chem. 2008, 391, 1147-1152.

[45] J.-B. Fini, S. Pallud-MothreÌ• , S. b. Le MeÌ• vel, K. Palmier, C. M. Havens, M. Le Brun, V. Mataix, G. F. Lemkine, B. A. Demeneix, N. Turque and P. E. Johnson, Environ. Sci. Technol. 2009, 43, 8895-8900.

[46] D. Li, M. He and S. C. Jiang, Appl. Environ. Microb. 2010, 76, 1442-1448.

[47] N. Watkins, B. M. Venkatesan, M. Toner, W. Rodriguez and R. Bashir, Lab Chip 2009, 9.

[48] S. Joo, K. H. Kim, H. C. Kim and T. D. Chung, Biosens. Bioelectron. 2010, 25, 1509-1515.

[49] A. Dove, Aquat. Ecosyst. Health. 2009, 12, 281-295.

[50] H. Zipper, H. Brunner, J. Bernhagen and F. Vitzthum, Nucleic Acids Res. 2004, 32, e103. 